\title{
Infraspecific chemical variability of the leaf essential oil of Juniperus phoenicea var. turbinata from Portugal
}

\author{
Carlos Cavaleiro ${ }^{\mathrm{a}, *}$, Serge Rezzi ${ }^{\mathrm{b}}$, Ligia Salgueiro ${ }^{\mathrm{a}}$, \\ Ange Bighelli ${ }^{\mathrm{b}}$, Joseph Casanova ${ }^{\mathrm{b}}$, \\ António Proença da Cunha ${ }^{\mathrm{a}}$ \\ ${ }^{a}$ C.E.F./Laboratório de Farmacognosia, Faculdade de Farmácia, Universidade de Coimbra, Rua do Norte, \\ 3000 Coimbra, Portugal \\ ${ }^{\mathrm{b}}$ Université de Corse, Equipe Chimie et Biomasse, URA CNRS 2053, Route des Sanguinaires, 20000 Ajaccio, \\ France
}

Received 15 June 2000; accepted 30 December 2000

\begin{abstract}
The essential oil composition of 68 individual plants of Juniperus phoenicea from Portugal was investigated by GC, GC-MS and ${ }^{13} \mathrm{C}$ NMR. $\alpha$-Pinene, $\beta$-phellandrene, $\alpha$-terpinyl acetate and myrcene were found to be the main constituents. Botanical and chemical data as well as phytogeographical distribution indicate $J$. phoenicea var. turbinata as the unique subspecies occurring in Portugal. Nevertheless, this taxon exhibits chemical polymorphism. The results of the oil compositions were processed by hierarchical clustering and principal component analysis allowing to establish three groups of essential oils differentiated by the content of $\alpha$-pinene, $\beta$-phellandrene and $\alpha$-terpinyl acetate. (C) 2001 Elsevier Science Ltd. All rights reserved.
\end{abstract}

Keywords: Juniperus phoenicea var. turbinata; Cupressaceae; Essential oil; GC; GC-MS; ${ }^{13} \mathrm{C}$ NMR; Infraspecific variability

\section{Introduction}

Juniperus phoenicea L. is a native species of Portugal but some taxonomic problems subsist at subspecific level. Franco (1986) reported the occurrence in

*Corresponding author. Tel.: + 351-239-859-995; fax: +351-239-827-126.

E-mail address: cavaleir@ff.uc.pt (C. Cavaleiro). 
Portugal of a unique subspecies, J. phoenicea subsp. phoenicea L., while Costa et al. (1993) mention only Juniperus phoenicea subsp. turbinata (Guss.) Parl. Nyman. (=J. phoenicea subsp. lycia Auct. $=J$. turbinata Guss.). A chemotaxonomic study of Juniperus phoenicea based on the ratio of the leaf prodelphinidine/ procyanidine led a new taxon, J. phoenicea subsp. eu-mediterranea Lebr. \& Tiv. (Lebreton and Thivend, 1981), considered later as the unique subspecies occurring in Portugal (Lebreton, 1983). The controversy about the taxonomy of the portuguese populations of Juniperus phoenicea was partially solved by the comparison of the essential oil composition from var. turbinata and subsp. eu-mediterranea (Adams et al., 1996). The similar compositions of the oils of var. turbinata from Spain and subsp. eu-mediterranea from Portugal, with important amounts of $\alpha$-pinene, $\beta$-phellandrene and $\alpha$-terpinyl acetate, lead the authors to conclude that var. turbinata and subsp. eu-mediterranea are conspecific but different from $J$. phoenicea var. phoenicea whose oil has higher quantities of $\alpha$-pinene and lower of $\beta$-phellandrene.

Studies on the composition of the essential oil of $J$. phoenicea from Portugal (Cavaleiro et al., 1996) showed that among portuguese populations other oil composition patterns were present. Distinct compositions were also found in the Corsican populations of $J$. phoenicea (Rezzi et al., 2001).

The aim of this study was to evaluate, analyzing isolated plants from a large number of portuguese populations, the significance of the variability of the leaf essential oil and discuss its contribution for the taxonomy and characterization of infraspecific variability of $J$. phoenicea.

\section{Materials and methods}

\subsection{Plant material}

Sixty-eight samples of single plants were collected in the areas of distribution of $J$. phoenicea, specially in the littoral south and center of Portugal: Costa Vicentina-Vila do Bispo (samples 1-14), Sudoeste Alentejano-Porto Covo (15-24), Noroeste Alentejano-Melides (25-28), Península de Troia-Troia (29-43), Península de SetúbalSerra da Arrábida (44-58), Cabo Mondego-Gala $(59-62,68)$ and Guadiana interiorMértola (63-67).

Voucher specimens were deposited in the Herbarium of the Instituto Botânico of the University of Coimbra (COI).

\subsection{Sampling and essential oils isolation}

Leaves were collected during the period of May-September of 1995-97, when the plants exhibit a majority of mature berries, and submitted to water distillation for $3 \mathrm{~h}$ using a Clevenger-type apparatus. Essential oil yield, ranged between $0.2 \%$ and $0.9 \%(\mathrm{v} / \mathrm{w}$, from fresh material). 


\subsection{GC, GC/MS and ${ }^{13}$ carbon NMR analyses}

Analytical GC was carried out on an Hewlett Packard 6890 gas chromatograph with HP GC ChemStation Rev. A.05.04 data handling system, equipped with a single injector and two flame ionization detectors (FID). Two fused silica capillary columns with different polarities were used: SPB-1 (polydimethylsiloxane $30 \mathrm{~m} \times 0.20 \mathrm{~mm}$ i.d., film thickness $0.20 \mu \mathrm{m}$ ), and SupelcoWax 10 (polyethyleneglycol $30 \mathrm{~m} \times 0.20 \mathrm{~mm}$ i.d., film thickness $0.20 \mu \mathrm{m})$. Oven temperature program: $70^{\circ} \mathrm{C}-220^{\circ} \mathrm{C}\left(3^{\circ} \mathrm{C} / \mathrm{min}\right), 220^{\circ} \mathrm{C}$ (15 min); injector temperature: $250^{\circ} \mathrm{C}$; carrier gas: helium, adjusted to a linear velocity of $30 \mathrm{~m} / \mathrm{s}$; splitting ratio $1: 40$; detectors temperature: $250^{\circ} \mathrm{C}$.

Relative amounts of individual components were calculated based on peak areas without FID response factor correction. Retention indices were determined by linear interpolation relative to retention times of a series of $n$-alkanes.

GC-MS was performed with an Hewlett Packard 6890 gas chromatograph, with a HP1 fused silica column (polydimethylsiloxane $30 \mathrm{~m} \times 0.25 \mathrm{~mm}$ i.d., film thickness $0.25 \mu \mathrm{m}$ ), interfaced with an Hewlett Packard Mass Selective Detector 5973 operated by HP Enhanced ChemStation software, version A.03.00. GC parameters as above; interface temperature: $250^{\circ} \mathrm{C}$; MS source temperature: $230^{\circ} \mathrm{C}$; MS quadrupole temperature: $150^{\circ} \mathrm{C}$; ionization energy: $70 \mathrm{eV}$; ionization current: $60 \mu \mathrm{A}$; scan range: 35-350u; scans/s: 4.51.

${ }^{13} \mathrm{C}-\mathrm{NMR}$ spectra were recorded on a Bruker AC 200 Fourier Transform Spectrometer, operating at $50.323 \mathrm{MHz}$, equipped with a $10 \mathrm{~mm}$ probe in deuterated chloroform (around $200 \mathrm{mg}$ of oil in $2 \mathrm{ml}$ of $\mathrm{CDCl}_{3}$ ) with all shifts referred to internal tetramethylsilane (TMS). Parameters: pulse width (PW): $5.0 \mu$ s (flip angle $45^{\circ}$ ); acquisition time: $1.3 \mathrm{~s}$ and relaxation delay $\mathrm{D}_{1}: 2 \mathrm{~s}$ (total recycling time $3.3 \mathrm{~s}$ ) for $32 \mathrm{~K}$ data table with a spectral width (SW) of $12,500 \mathrm{~Hz}(250 \mathrm{ppm})$; Composite Phase Decoupling (CPD) of the proton band; digital resolution: $0.763 \mathrm{~Hz} / \mathrm{pt} ; 5000$ scans were accumulated for each sample. An exponential multiplication of the free induction decay with the line broadening of $1.0 \mathrm{~Hz}$ was applied before Fourier transformation.

The constituents of the essential oils were identified on the basis of their GC retention indices $(\mathrm{RI})$, and by matching their $70 \mathrm{eV}$ mass spectra with our own data and reference libraries (Adams, 1995; Joulain and König, 1998; McLafferty and Stauffer, 1989). Major compounds were also identified by ${ }^{13} \mathrm{C}-\mathrm{NMR}$. The identification was performed by computer-aided analysis of the ${ }^{13} \mathrm{C}-\mathrm{NMR}$ spectrum of the total oil, by comparing the signals obtained with those of pure compounds included in a library created in our laboratory (Tomi et al., 1995; Rezzi et al., 2001). This ${ }^{13} \mathrm{C}$-NMR technique has proved to be useful for the identification of ambiguous components (detection limit: $0.5 \%$ ) which are poorly separated by GC or insufficiently elucidated by mass spectra and retention indices.

\subsection{Data analysis}

The compositional data of 68 investigated samples of $J$. phoenicea var turbinata from Portugal and data of four reference samples obtained from literature (Adams 
et al., 1996) - two samples of J. phoenicea var. phoenicea (cases 69-70), one sample of $J$. phoenicea var. turbinata (case 71) and one sample of J. phoenicea ssp. eumediterranea (case 72) - were submitted to Multivariate Statistic Analysis accomplished by SPSS (Superior Performing Software Systems, Inc.) 10.0. Only the 40 constituents over $0.5 \%$ were used as variables for analysis.

Data was subject to a hierarchical clustering using average linkage with square Euclidean distance measure and factor analysis using the Principal Components extraction method (PCA). The aptitude of the complete correlation matrix was checked by the Kaiser Meyer-Olkin criterion $(\mathrm{KMO}=0.519)$. After PCA, another hierarchical clustering concerning to the two extracted principal components was performed.

\section{Results and discussion}

Sixty-eight components amounting from 86.9 to $99.8 \%$ of the total oil were identified (Table 1). $\alpha$-Pinene, $\beta$-phellandrene, $\alpha$-terpinyl acetate, and myrcene were found to be the main constituents. From hierarchical clustering dendrogram (Fig. 1), the 68 samples of J. phoenicea var. turbinata from Portugal as well as the reference samples of $J$. phoenicea var. turbinata and $J$. phoenicea ssp. eumediterranea were classified in three significant clusters (clusters A, B, and C). Reference cases of $J$. phoenicea var. phoenicea were classified apart in another cluster (cluster D).

PCA reduced the 40 variables to two principal components representing $95.2 \%$ of the total variance, having $\alpha$-pinene, $\beta$-phellandrene and $\alpha$-terpinyl acetate the highest coefficient factors. The hierarchical classification relative to the two extracted components confirmed clustering based in the original variables.

PCA, together with both hierarchical classifications (Fig. 2) allowed establish four types of essential oils characterized in the base of their $\alpha$-pinene, $\beta$-phellandrene and $\alpha$-terpinyl acetate contents.

Two clusters (A and B) were differentiated in the basis of their $\alpha$-pinene, $\beta$ phellandrene and $\alpha$-terpinyl acetate ratios: the oils of cluster $A(63.2 \%$ of the samples) are characterized by $\alpha$-pinene (average $=44.3 \%, \mathrm{SD}=6.4), \beta$-phellandrene (average $=22.7 \%, \mathrm{SD}=3.5$ ) and $\alpha$-terpinyl acetate (average $=6.9 \%, \mathrm{SD}=2.3$ ), the ratio $\alpha$-pinene: $\beta$-phellandrene is close to $2: 1$; essential oils of cluster B $(32.4 \%$ of the samples) are also characterized by $\alpha$-pinene (average $=27.8 \%, \mathrm{SD}=4.8$ ), $\beta$ phellandrene $($ average $=28.8 \%, \mathrm{SD}=3.2$ ) and $\alpha$-terpinyl acetate $($ average $=10.5 \%$, $\mathrm{SD}=3.1$ ) but the ratio $\alpha$-pinene: $\beta$-phellandrene is close to 1 . The composition of the oils from cluster B is similar to those reported for oils of $J$. phoenicea var. turbinata from Spain (reference case 71) (Adams et al., 1996), while composition oils from cluster A is similar to those $J$. phoenicea subsp. eu-mediterranea (reference case 72) (Adams et al., 1996) and those of plants from $J$. phoenicea var. turbinata growing in Corsica (Rezzi et al., 2001). The essential oils of cluster C (4.4\% of the samples) are dominated by $\alpha$-pinene (average $=81.5 \%, \mathrm{SD}=4.8$ ). This extremely high content of $\alpha$-pinene was not yet reported for $J$. phoenicea leaf oil but only described for oils 
Table 1

Composition of the essential oils of the three clusters of $J$. phoenicea var. turbinata from Portugal ${ }^{\mathrm{a}}$

\begin{tabular}{|c|c|c|c|c|}
\hline \multirow[t]{2}{*}{ Components } & \multirow[t]{2}{*}{$\mathrm{RI}^{\mathrm{b}}$} & \multicolumn{3}{|c|}{$\%$ Average (range) } \\
\hline & & Cluster A & Cluster B & Cluster C \\
\hline Tricyclene & 921 & $0.1(0-0.3)$ & $0.1(0-0.2)$ & $0.2(0.2-0.3)$ \\
\hline$\alpha$-Pinene ${ }^{c}$ & 930 & $44.3(35.6-63.2)$ & $27.8(18.1-35.7)$ & $81.5(76.3-85.8)$ \\
\hline$\alpha$-Fenchene & 941 & $0.2(0-0.9)$ & $0.1(0-0.9)$ & $0.1(0-0.4)$ \\
\hline Camphene & 941 & $0.3(t-0.8)$ & $0.3(0.1-0.7)$ & $0.6(0.4-1.0)$ \\
\hline Sabinene & 964 & $0.1(t-0.4)$ & $0.3(t-0.4)$ & $0.1(0.1-0.2)$ \\
\hline$\beta$-Pinene ${ }^{\mathrm{c}}$ & 970 & $1.3(0.9-1.8)$ & $1.2(0.6-1.8)$ & $1.2(0.8-1.4)$ \\
\hline Myrcene $^{c}$ & 980 & $6.3(4.1-7.9)$ & $7.1(5.3-11.0)$ & $2.5(2.2-2.8)$ \\
\hline$\alpha$-Phellandrene ${ }^{c}$ & 997 & $3.6(1.1-4.9)$ & $4.1(2.1-5.4)$ & $0.1(0.1-0.2)$ \\
\hline$\Delta$-2-Carene ${ }^{\mathrm{c}}$ & 998 & $0.6(t-1.8)$ & $0.9(t-2.4)$ & $t(0-t)$ \\
\hline$\Delta$-3-Carene & 1005 & $0.2(0-7.8)$ & $0.3(0-6.2)$ & $t(0-0.1)$ \\
\hline$\alpha$-Terpinene & 1010 & $0.4(t-1.4)$ & $0.4(0.1-0.7)$ & $t(0-0.1)$ \\
\hline$p$-Cymene ${ }^{c}$ & 1011 & $1.0(0.6-2.2)$ & $1.2(0.8-2.3)$ & $0.2(0.2-0.3)$ \\
\hline Limonene $^{c}$ & 1020 & $2.3(0.3-5.7)$ & $2.5(1.4-4.0)$ & $1.4(0.9-2.3)$ \\
\hline$\beta$-Phellandrene ${ }^{\mathrm{c}}$ & 1020 & $22.7(13.4-31.5)$ & $28.8(24.9-38.0)$ & $0.4(0.4-0.5)$ \\
\hline$E$ - $\beta$-Ocimene & 1035 & $t(0-0.1)$ & - & $t(0-t)$ \\
\hline$\gamma$-Terpinene ${ }^{c}$ & 1047 & $0.3(0.1-0.4)$ & $0.3(t-0.6)$ & $0.3(0.3-0.4)$ \\
\hline Fenchone & 1066 & $t(0-0.19)$ & $t(0-0.1)$ & $0.1(0-0.2)$ \\
\hline Cymenene & 1071 & $0.1(0-0.2)$ & $0.1(0-0.2)$ & $t(0-0.1)$ \\
\hline Terpinolene $^{c}$ & 1077 & $1.3(0.6-1.8)$ & $1.6(1.2-1.9)$ & $0.5(0.5-0.5)$ \\
\hline Linalool & 1082 & $0.1(0-0.4)$ & $0.2(0-0.7)$ & $0.5(0.2-0.9)$ \\
\hline$\alpha$-Fenchol & 1098 & $t(0-0.1)$ & $t(0-0.1)$ & $0.1(0-0.1)$ \\
\hline$\alpha$-Campholenal & 1104 & $0.1(0-0.3)$ & $t(0-0.1)$ & $0.1(0-0.1)$ \\
\hline$Z$-p-Menth-2-en-1-ol & 1106 & $0.3(0-0.7)$ & $0.5(0-1.2)$ & $0.1(0-0.4)$ \\
\hline Camphor & 1119 & $t(0-0.1)$ & $t(0-0.1)$ & - \\
\hline$E$-p-Menth-2-en-1-ol & 1120 & $0.4(0-0.9)$ & $0.4(0-0.9)$ & - \\
\hline cis-Verbenol & 1126 & $0.1(0-0.3)$ & $0.1(0-0.3)$ & $0.1(0-0.2)$ \\
\hline Isoborneol & 1138 & $0.1(0-0.4)$ & $t(0-0.2)$ & $0.1(0-0.2)$ \\
\hline$p$-Mentha-1,5-dien-8-ol & 1143 & $0.1(0-0.3)$ & $0.1(0-0.3)$ & - \\
\hline Cryptone & 1152 & $0.1(0-0.3)$ & $0.1(0-0.4)$ & - \\
\hline p-Cymene-8-ol & 1158 & $0.1(0-0.4)$ & $0.1(0-0.3)$ & $t(0-0.1)$ \\
\hline Terpineol-4 & 1158 & $0.1(0-0.3)$ & $0.2(t-0.3)$ & $0.2(t-0.4)$ \\
\hline$\alpha$-Terpineol & 1169 & $0.7(0-1.6)$ & $0.9(0.5-1.4)$ & $0.5(0.3-0.8)$ \\
\hline cis-Piperitol & 1177 & $0.1(0-0.3)$ & $0.2(0-0.4)$ & $0.1(0-0.3)$ \\
\hline trans-Piperitol & 1187 & $0.1(0-0.4)$ & $0.2(0-0.4)$ & $t(0-0.1)$ \\
\hline cis-Carveol & 1195 & $t(0-0.2)$ & $t(0-0.1)$ & - \\
\hline Fenchyl acetate & 1204 & $0.1(0-0.2)$ & $t(0-0.2)$ & $0.2(0.2-0.3)$ \\
\hline Citronellol $^{\mathrm{c}}$ & 1210 & $0.3(0-1.5)$ & $0.6(0-2.2)$ & $t(0-0.1)$ \\
\hline trans-Carveol & 1212 & $t(0-0.2)$ & $t(0-0.2)$ & - \\
\hline Piperitone & 1222 & $0.2(0-0.6)$ & $0.3(0-0.6)$ & - \\
\hline Geraniol & 1233 & $t(0-0.2)$ & $t(0-0.4)$ & $0.1(0-0.2)$ \\
\hline 3-Decene-1-ol & 1238 & $0.2(0-0.9)$ & $0.4(0-0.9)$ & $0.2(0-0.5)$ \\
\hline Linalyl acetate & 1240 & $0.1(0-0.2)$ & $0.1(0-0.2)$ & $0.4(0-1.1)$ \\
\hline Isopulegyl acetate $^{c}$ & 1254 & $0.3(0-1.4)$ & $0.2(0-1.6)$ & - \\
\hline Bornyl acetate & 1267 & $0.3(0-0.6)$ & $0.4(0-1.2)$ & $0.7(0.3-0.9)$ \\
\hline$\alpha$-Terpenyl acetate ${ }^{c}$ & 1331 & $6.9(2.2-11.9)$ & $10.5(3.1-15.0)$ & $0.3(0.1-0.4)$ \\
\hline$\beta$-Elemene & 1382 & $t(0-0.3)$ & $0.1(0-0.5)$ & $t(0-0.1)$ \\
\hline$E$-Caryophyllene & 1408 & $0.1(0-0.3)$ & $0.2(0.1-0.6)$ & $0.2(0.1-0.3)$ \\
\hline
\end{tabular}


Table 1 (continued)

\begin{tabular}{|c|c|c|c|c|}
\hline \multirow[t]{2}{*}{ Components } & \multirow[t]{2}{*}{$\mathrm{RI}^{\mathrm{b}}$} & \multicolumn{3}{|c|}{$\%$ Average (range) } \\
\hline & & Cluster A & Cluster B & Cluster C \\
\hline$\gamma$-Elemene & 1422 & $t(0-0.1)$ & $t(0-0.2)$ & - \\
\hline$\alpha$-Humulene & 1442 & $t(0-0.2)$ & $t(0-0.2)$ & $0.1(0-0.2)$ \\
\hline Germacrene D & 1467 & $0.2(0-0.6)$ & $0.3(0-1.1)$ & $0.3(0.1-0.4)$ \\
\hline$\alpha$-Muurolene & 1486 & $0.1(0-0.4)$ & $0.1(0-0.4)$ & $0.1(0-0.2)$ \\
\hline$\gamma$-Cadinene & 1498 & $0.1(0-0.3)$ & $0.1(0-0.4)$ & $0.2(t-0.2)$ \\
\hline cis-Calamelene & 1502 & $t(0-0.1)$ & $t(0-0.9)$ & - \\
\hline$\delta$-Cadinene ${ }^{\mathrm{c}}$ & 1508 & $0.3(0.1-0.8)$ & $0.5(0.2-0.9)$ & $0.6(0.2-0.8)$ \\
\hline Elemol & 1526 & $0.3(0-0.7)$ & $0.4(0.2-0.8)$ & $0.4(0.2-0.5)$ \\
\hline Germacrene B & 1540 & $0.2(0-0.9)$ & $0.3(0-0.9)$ & $t(0-0.1)$ \\
\hline Nerolidol & 1545 & $t(0-0.2)$ & $t(0-0.4)$ & $0.2(0-0.5)$ \\
\hline Caryophyllene oxide & 1557 & $0.1(0-0.3)$ & $0.1(0-0.3)$ & $t(0-0.1)$ \\
\hline$\alpha$-Cedrol & 1575 & - & $0.4(0-5.4)$ & - \\
\hline Humulene epoxide & 1582 & $t(0-0.1)$ & $0.0(0-0.1)$ & - \\
\hline$\gamma$-Eudesmol & 1607 & $t(0-0.2)$ & $0.1(0-0.3)$ & - \\
\hline$\alpha$-Cadinol & 1616 & $0.1(0-0.3)$ & $0.2(0-0.5)$ & $0.2(0-0.5)$ \\
\hline$\beta$-Eudesmol & 1620 & $t(0-0.3)$ & $0.1(0-1.3)$ & $0.2(0-0.3)$ \\
\hline$\tau$-Muurolol & 1627 & $0.3(0-0.7)$ & $0.5(0.2-1.5)$ & $0.6(0.1-1.3)$ \\
\hline Sandaracopimaradiene & 1941 & $t(0-0.3)$ & $t(0-0.3)$ & $t(0-t)$ \\
\hline Manoyl oxide ${ }^{\mathrm{c}}$ & 1964 & $0.1(0-1.3)$ & $0.2(0-1.0)$ & $t(0-0.1)$ \\
\hline Abietatriene & 2018 & $t(0-0.2)$ & $t(0-0.4)$ & $0.1(0-0.2)$ \\
\hline Totarol $^{\mathrm{c}}$ & 2253 & $t(0-0.6)$ & $0.2(0-1.0)$ & $0.3(0-0.6)$ \\
\hline Monoterpene hydrocarbons & & $89.6(84.1-94.6)$ & $76.8(60.1-88.1)$ & $85.0(74.7-93.7)$ \\
\hline Oxygen containing monoterpenes & & $3.3(1.8-4.6)$ & $15.3(7.9-23.8)$ & $10.5(3.6-17.3)$ \\
\hline Sesquiterpene hydrocarbons & & $1.5(0.6-2.0)$ & $1.6(0.4-4.9)$ & $1.1(0.3-2.2)$ \\
\hline Oxygen containing sesquiterpenes & & $1.7(0.4-2.6)$ & $2.0(0.4-8.5)$ & $0.9(0-1.8)$ \\
\hline Others & & $0.5(0.1-0.8)$ & $0.9(0-2.3)$ & $0.4(0-1.8)$ \\
\hline Total identified & & $96.5(93.8-99.7)$ & $96.5(88.0-99.6)$ & $97.8(86.9-99.8)$ \\
\hline
\end{tabular}

${ }^{\mathrm{a}}=\operatorname{traces}(<0.05 \%)$.

${ }^{\mathrm{b}}$ Retention index on the SPB-1 column.

${ }^{\mathrm{c}}$ Identity confirmed by ${ }^{13} \mathrm{C}-\mathrm{NMR}$.

isolated from berries (Proenca da Cunha et al., 1977; De Pascual Teresa et al., 1981; Vidrich and Michelozzi, 1993; Falchi Delitala, 1980; Lawrence, 1989).

Composition patterns corresponding to clusters A and B are present in all the collection areas with a similar distribution, excepting Península de Troia and Península de Setúbal, where oils of cluster A are dominant. Composition pattern corresponding to cluster $\mathrm{C}$ (three samples) was only detected in Costa Vicentina, Sudoeste Alentejano and Cabo Mondego.

No conspicuous botanical differences were observed among the plants and, in other hand, plants with distinct oil composition are present in each population and from different habitats. The littoral distribution, the morphological features and the chemical data, including the comparison with the reference samples of $J$. phoenicea var turbinata, J. phoenicea subsp eu-mediterranea and J. phoenicea var. phoenicea, lead us to consider Juniperus phoenicea var. turbinata the unique variety spontaneous 


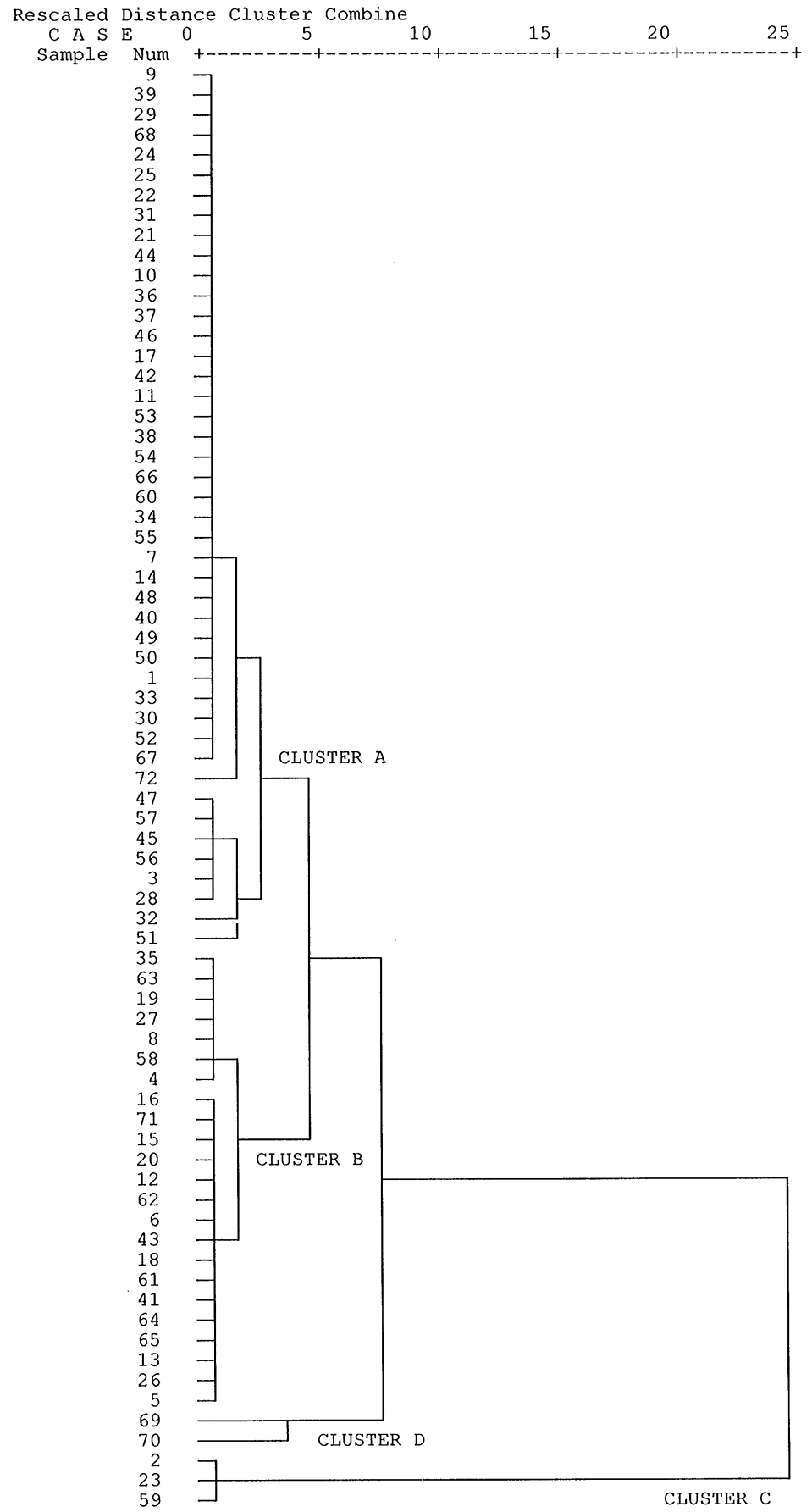

Fig. 1. Dendrogram from the hierarchical cluster analysis based in the original variables. 


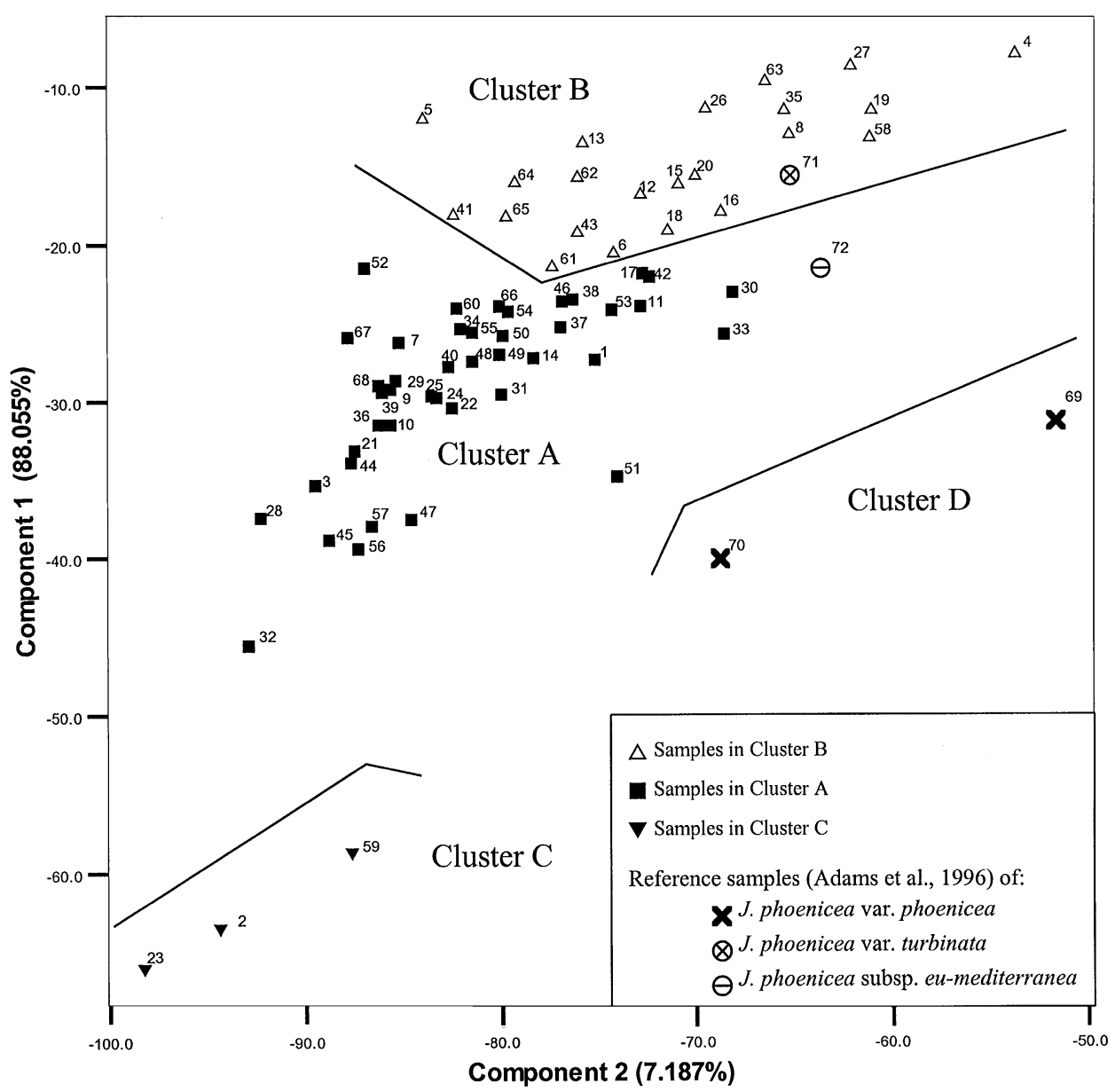

Fig. 2. Scatterplot of the samples for the two principal components extracted in PCA.

from Portugal. Nevertheless it appears from our results that the portuguese $J$. phoenicea var. turbinata exhibit an infraspecific chemical variability with two dominant types of essential oils.

\section{Acknowledgements}

We thank Dr. Armando Moura for his invaluable help in prospecting and plant collection, Prof. Jorge Paiva for J. phoenicea taxonomy, Prof. José Barroso and Prof. Ana Cristina Figueiredo for their contribution in GC-MS analysis. Thanks are also due to JNICT (Portugal) for financial support (PBIC/BIA1995), and to JNICT and Embassy of France in Portugal for travel grants. 


\section{References}

Adams, R.P., 1995. Identification of Essential Oil Components by Gas Chromatography/Mass Spectroscopy. Allured Publishing Corporation, Carol Stream, IL, USA.

Adams, R.P., Barrero, A.F., Lara, A., 1996. Comparisons of the leaf essential oils of Juniperus phoenicea, $J$ phoenicea subsp. eu-mediterranea Lebr. \& Thiv. and J. phoenicea var. turbinata (Guss) Parl. J. Essential Oil Res. 8, 367-371.

Cavaleiro, C., Salgueiro, L., Figueiredo, A.C., Barroso, J., Roque, O., Proenca da Cunha, A., 1996. Composition of the essential oil of Juniperus phoenicea L. from Portugal. Poster presented to the 27th International Symposium on Essential Oils, Vienna, Austria, September, 1996.

Costa, J.C., Capelo, J.H., Lousã, M.F., Aguiar, C., 1993. Communautés de Juniperus au Portugal. Colloq. Phytosociol. 12, 499-526.

De Pascual Teresa, J., Barrero, A.F., Caballero, M.C., Ramos, M.A., San Feliciano, A., 1981. Componentes de las arcestidas de Juniperus phoenicea Linnaeus aceite esencial. Riv. Ital. EPPOS. 62, 353-354.

Falchi Delitala, L., 1980. Ricerche chemiotassonomiche sul genere Juniperus Linnaeus. Riv. Ital. EPPOS. 62, 303-309.

Franco, J. A., 1986. Juniperus L. In: Castroviejo, S., Laínz, M., López González, G., Montserrat, P., Muñoz Garmendia, F., Paiva, J. and Villar, L. (Eds.), Flora Iberica, Vol. I. Real Jardín Botánico, C.S.I.C., Madrid, pp. 181-188.

Joulain, D., König, W.A., 1998. The Atlas of Spectral Data of Sesquiterpene Hydrocarbons. E.B.-Verlag, Hamburg.

Lawrence, B. M., 1989. Juniper-berry oil. Essential Oils (1987-1988). Allured Publishing Corporation, Wheaton, pp. 240-241.

Lebreton, P., 1983. Nouvelles données sur la distribution au Portugal et en Espagne de sous-espèces du genévrier de phoenicie (Juniperus phoenicea L). Agronomia lusit. 42, 55-62.

Lebreton, P., Thivend, S., 1981. Sur une sous-espèce du genevrier de phoenicie Juniperus phoenicea L., définie à partir de critères biochimiques. Nat. Monspeliensia Ser. Bot. 47, 1-12.

McLafferty, F.W., Stauffer, D.B., 1989. The Wiley/NBS Registry of Mass Spectral Data. Wiley, New York.

Proenca da Cunha, A., Roque, O.R., Cardoso do Vale, J., 1977. Novos ensaios na essência de Juniperus phoenicea L. Bol. Fac. Farm. Coimbra. 2, 9-23.

Rezzi, S., Cavaleiro, C., Bighelli, A., Salgueiro, L., Proenca da Cunha, A., Casanova, J., 2001. Intraspecific variability of the leaf essential oil of Juniperus phoenicea subsp. turbinata from Corsica. Biochem. Systematics Ecol. 29, 179-188.

Tomi, F., Bradesi, P., Bighelli, A., Casanova, J., 1995. Computer-aided identification of individual components of essential oils using ${ }^{13}$ carbon NMR spectroscopy. J. Magn. Reson. Anal. 1, $25-34$.

Vidrich, V., Michelozzi, M., 1993. Sulla resa e compozione stagionale di olio essenziale di galbule e foglie di Juniperus phoenicea L. Italia Forestale e Montana 48 (2), 133-140. 